\title{
ANL/ET/CP-8/606
}

\section{PROPERTIES OF V-4CR-4TI FOR APPLICATION AS FUSION REACTOR STRUCTURAL COMPONENTS*}

by

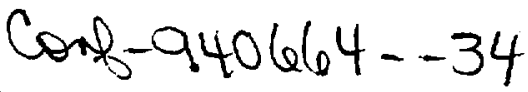

H. M. Chung, B. A. Loomis, and D. L. Smith

Argonne National Laboratory

Argonne, IL 60439 U.S.A.

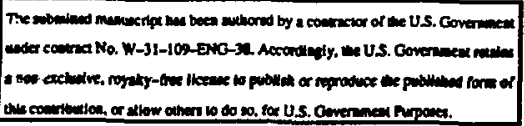

August 1994

\section{DISCLAIMER}

This report was prepared as an account of work sponsored by an agency of the United States Government. Neither the United States Government nor any agency thereof, nor any of their employees, makes any warranty, express or implied, or assumes any legal liability or responsibility for the accuracy, completeness, or usefulness of any information, apparatus, product, or process disclosed, or represents that its use would not infringe privately owned rights. Reference herein to any specific commercial product, process, or service by trade name, trademark, manufacturer, of otherwise does not necessarily constitute or imply its endorsement, recommendation, or favoring by the United States Government or any agency thereof. The views and opinions of athors expressed berein do not necesearily state or reflect thowe of the Unitod States Government or any agency thereof.

Presented at the Third International Symposium on Fusion Nuclear Technology, June 27-July 1. 1994, Los Angeles, CA, and to be published in Fusion Engineering and Design.

Work supported by the U.S. Department of Energy, Office of Fusion Energy, under Contract W-31-109-Eng-38. 


\title{
PROPERTIES OF V-4CT-4TI FOR APPLICATION AS FUSION REACTOR STRUCTURAL COMPONENTS*
}

\author{
H. M. Chung, B. A. Loomis, and D. L. Smith \\ Argonne National Laboratory \\ Argonne, IL 60439 \\ U.S.A.
}

\begin{abstract}
Vanadium-base alloys are promising candidate materials for application in fusion reactor first-wall and blanket structures because they offer several important advantages, i.e., inherently low irradiation-induced activity, good mechanical properties, good compatibility with lithium, high thermal conductivity, and good resistance to irradiation-induced swelling and damage. As pait of a program to screen candidate alloys and develop an optimized vanadium-base alloy, extensive investigations of various $\mathrm{V}-\mathrm{Ti}, \mathrm{V}-\mathrm{Cr}-\mathrm{Tl}$, and $\mathrm{V}-\mathrm{TI}-\mathrm{Si}$ alloys have been conducted after irradiation in lithium in fission reactors. From these investigations, V-4 wt. \% $\mathrm{Cr}-4$ wt.\%Ti was identifled as the most promising alloy. The alloy exhibited attractive mechanical and physical properties that are prerequisites for first-wall and blanket structures, 1.e., high tensile strength, high ductility, good creep properties, high impact energy, low ductile-brittle transition temperature before and after irradiation, excellent resistance to irradiation-induced swelling and microstructural instability, and good resistance to corrosion in lithium. In particular, the alloy is virtually immune to irradiation-induced embrittlement, a remarkable property compared to other candidate materials being investigated in the fusion-reactor-maticials community. Effects of helium, charged dynamically in simulation of realistic fusion reactor conditions, on tensile, ductile-brittle transition, and swelling properties were insignificant. Thermal creep behavior of the alloy was significantly superior to that of austenitic and ferritic/martensitic steels.
\end{abstract}

\section{Introduction}

Vanadium-base alloys have significant advantages over other candidate alloys (such as austenitic and ferritic steels) for use as structural materials in fusion devices, e.g., the International Thermonuclear Experimental Reactor (ITER) and magnetic fusion reactors. These advantages include intrinsically lower levels of long-term activation. irradiation afterheat, neutron-induced helium- and hydrogen-transmutation rates, biological hazard potential, and thermal stress factor. ${ }^{1-5}$ However, to make use of these favorable neutronic and physical properties of structural materials in fusion systems, the alloys must be resistant to neutron-induced swelling, creep, and embrittlement, and they must also be compatible with the reactor coolant and environmeat.

As part of a program to screen candidate alloys and develop an optimal alloy, extensive Investigations have been conducted on the swelling behavior, tensile properties, impact toughness, and microstriscturæl evolution of V, V-Ti, V-Cr, V-Cs-TI, and V-Ti-Si alloys after

Work supported by the U.S. Department of Energy, Office of Fusion Energy, under Contract W-31-109-Eng-38. 
irradiation by fast neutrons at 420,520 , and $600^{\circ} \mathrm{C}$. These investigations revealed that $\mathrm{V}$ Cr-Ti alloys containing 4-5 wt.\% Cr, 3-5 at.\% Ti, 400-1000 wt. ppm Si. and <1000 wt. ppm $\mathrm{O}+\mathrm{N}+\mathrm{C}$ were most desirable because they exhibit superior resistance to swelling. embrittlement, and hydrogen-induced effects during fast-neutron irradiation in lithium.6-10 As a result, recent attention has focused primarlly on the ternary alloys $\mathrm{V}-(4-5) \mathrm{Cr}-(3-5) \mathrm{TH}$, and on the binary alloy V-5Ti.

Subsequently, a heat of $\mathrm{V}-4 \mathrm{Cr}-4 \mathrm{Ti}$ alloy containing $\approx 800$ wppm silicone and $\approx 800$ wppm $\mathrm{O}+\mathrm{N}+\mathrm{C}$ has been fabricated and was selected for comprehensive testing and examination, particularly for the effects of fusion-relevant high-dose irradiation and ciynamically charged helium on the tensile, ductile-brittle-transition, Irradiation-induced density change and microstructural evolution, and thermal creep behavior. Results of this comprehensive investigation, as well as baseline properties of the alloy, are presented in this paper to provide insights and a database that are necessary to evaluate the alloy for application to fusion reactor first-wall and blanket structures.

\section{Materials and Irradiation}

The elemental composition of the $\mathrm{V}-4 \mathrm{Cr}-4 \mathrm{Ti}$ alloy, determined prior to irradiation, is given in Table 1 . The $30-\mathrm{kg}$ alloy ingot, melted from low-chlorine titanium and lowimpurity vanadium, was extruded at $1150^{\circ} \mathrm{C}$ and annealed at $1050^{\circ} \mathrm{C}$ several times after 810 passes of warm rolling between the anneal. Final forms of the product were annealed plates and sheets 3.8-, 1.0-, and 0.5-mm in thickness. Test specimens, machined from the annealed plates and sheets to investigate impact, tensile, and swelling behaviors and microstructural characteristics, were $\approx 95 \%$ recrystallized and exhibited an average grain stze of $\approx 14 \mu \mathrm{m}$. The only secondary phase present in the as-annealed specimen was $\mathrm{T}(\mathrm{O}, \mathrm{N}, \mathrm{C})$, which is normally observed in titanium-containing vanadium alloys with $\mathrm{O}+\mathrm{N}+\mathrm{C}$ $<400$ wppm. 11 Grain structure and precipitate distribution of the unirradiated material have been reported elsewhere. 12

Recently, a production-scale ingot of $\mathrm{V}-4 \mathrm{Cr}-4 \mathrm{Ti}$ weighing $\approx 500 \mathrm{~kg}$ has been melted and extruded successfully using essentially the same fabrication procedures. Initial tests on specimens machined from plates and sheets of this production heat indicated that Charpy-impact and tensile properties are as good as those of the $30-\mathrm{kg}$ heat. 
Table 1. Chemical composition of $V-4 C r-4 T i$ (ANL ID BL-47)

\begin{tabular}{|c|c|c|c|c|c|c|c|c|c|}
\hline \multirow[b]{2}{*}{ ANL ID } & \multirow{2}{*}{$\begin{array}{c}\text { Nominal } \\
\text { Composition } \\
\text { (wt.\%) }\end{array}$} & \multicolumn{8}{|c|}{ Impurity Composition (wppm) } \\
\hline & & 0 & $\mathbf{N}$ & $\mathbf{C}$ & SI & $\mathbf{S}$ & $\mathbf{P}$ & $\mathrm{Nb}$ & Mo \\
\hline BL-47 & $\mathrm{V}-4.1 \mathrm{Cr}-4.3 \mathrm{TI}$ & 350 & 220 & 200 & 870 & 20 & $<40$ & $<100$ & $<100$ \\
\hline
\end{tabular}

The alloy specimens were Irradiated in the Fast Flux Test Facility (FFTF), a fission test reactor located in Richland, Washington, at 420,520 , and $600^{\circ} \mathrm{C}$ to neutron fluences $(\mathrm{E}>$ $0.1 \mathrm{MeV}$ ) ranging from $3 \times 10^{22} \mathrm{n} / \mathrm{cm}^{2}$ (17 displacements per atom, or dpa) to $1.9 \times 10^{23}$ $\mathrm{n} / \mathrm{cm}^{2}$ (114 dpa). The specimens were sealed in TZM/Mo capsules filled with $99.99 \%$ enriched ${ }^{7} \mathrm{Li}$ during irradiation to prevent contamination by oxygen, nitrogen, and carbon impurities dissolved in the sodium coolant of the FFTF. In this type of irradiation test, designed to simulate and investigate the effects of displacement damage on the physical and mechanical properties of the alloy, formation of any appreciable levels of helium and trittum from ${ }^{6} \mathrm{LI}$ was avolded.

In contrast to the above type of irradiation test, the dynamic helium charging experiment (DHCE) was designed to simulate and investigate the effects of simultaneous displacement damage and fusion-relevant helium generation (at a ratio of $\approx 5$ appm helium/dpal on the properties of the alloy. During irradiation in the DHCE, the fusionrelevant helium-to-dpa ratio is simulated realistically by utilizing transmutation of controlled amounts of ${ }^{6} \mathrm{Li}$ and predetermined amount of tritium-doped vanadium mother alloy immersed in ${ }^{6} \mathrm{LI}+{ }^{7} \mathrm{Li} .{ }^{13,14}$ Table 2 summarizes the irradiation temperature, dose, tritium inventory charged at the beginning of irradiation, and measured helium and tritium

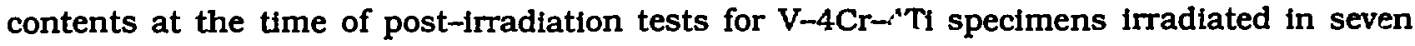
DHCE capsules.

The retrieved specimens were cleaned ultrasonically in alcohol prior to density measurement, microstructural analysis, Charpy-impact, tensile, and benaing tests. Bending tests were conducted on transmission electron microscopy (TEM) disks and pieces of fractured tensile specimens, irradiated in the DHCE, to determine ductile-brittle transition behavtor. Density change was determined from specimen weights measured in air and in research grade $\mathrm{CCl}_{4}$. Disk specimens were jet-thinned for analysis by TEM in a solution of $15 \%$ sulfuric acid- $72 \%$ methanol- $13 \%$ butyl cellosolve maintained at $-5^{\circ} \mathrm{C}$. 
Table 2.. Irradiation Parameters of Dynamic Helium Charging Experiment and Helium and Tritium Contents Measured in V-4Cr-4Tt Specimens

\begin{tabular}{|c|c|c|c|c|c|c|c|}
\hline $\begin{array}{l}\text { Capsule } \\
\text { ID No. }\end{array}$ & $\begin{array}{c}\text { Irradiation } \\
\text { Temp. } \\
\left({ }^{\circ} \mathrm{C}\right)\end{array}$ & $\begin{array}{c}\text { Initlal } \\
\text { Tritium } \\
\text { Charge } \\
\text { (C) } \\
\end{array}$ & $\begin{array}{c}\text { Total } \\
\text { Damage } \\
\text { (dpa) }\end{array}$ & $\begin{array}{c}\text { Calculated Helium } \\
\text { (appm) to dpa } \\
\text { Ratio at EOI } \\
\left.\text { (Assumed } k_{a} \text { or } k_{w}\right)^{c} \\
k_{a}=0.073\left(k_{y}=0.01\right) \\
\end{array}$ & $\begin{array}{c}\begin{array}{c}\text { Measured } \\
\text { Helium } \\
\text { Content }^{\mathrm{d}}\end{array} \\
\text { (appm) }\end{array}$ & $\begin{array}{c}\text { Actual } \\
\text { Helium to } \\
\text { dpa Ratio } \\
\text { (appm/dpa) }\end{array}$ & $\begin{array}{c}\text { Measured } \\
\text { Tritium } \\
\text { Contente } \\
\text { (appm) } \\
\end{array}$ \\
\hline 4D1 & 425 & 99 & 31 & 3.8 & $11.2-13.3$ & 0.39 & 27 \\
\hline 4D2 & 425 & 70 & 31 & 2.8 & $22.4-22.7$ & 0.73 & 39 \\
\hline $5 \mathrm{E} 2$ & 425 & 26 & 18 & 2.1 & $3.3-3.7$ & 0.11 & 2 \\
\hline 5D1 & 500 & 73.5 & 18 & 4.4 & $14.8-15.0$ & 0.83 & 4.5 \\
\hline $5 \mathrm{E}_{1}$ & 500 & 57 & 18 & 3.1 & $6.4-6.5$ & 0.36 & 1.7 \\
\hline $5 \mathrm{Cl}$ & 600 & 16.4 & 18 & 1.1 & $8.4-11.0$ & 0.54 & 20 \\
\hline $5 \mathrm{C2}$ & 600 & 18 & 18 & 1.1 & $74.9-75.3$ & 4.17 & 63 \\
\hline
\end{tabular}

a L. R. Greenwood "Revised Calculations for the DHCE," Aprll 30, 1993.

b Beginning of Irradiation (BO) May 27, 1991; end of irradiation (EOn) March 19, 1992; 203.3 effective full power days (EFPD), hot standby at $-220^{\circ} \mathrm{C}$ untll November 1992.

c Equilibrium ratio ( $k_{\mathrm{a}}$ by atom, $\mathrm{k}_{\mathrm{w}}$ by weight) of tritlum in $\mathrm{V}$ alloy to that in the surrounding liquid lithium.

d Measured June 1994.

e Measured August 1994.

\section{Tensile Properties}

Tensile properties of the unirradiated material, measured at $25^{\circ} \mathrm{C}$ in flowing argon at a strain rate of $0.0011 \mathrm{~s}^{-1}$, are summarized in Fig. 1. Yield and ultimate tensile strengths (Fig. 1A) were $\approx 402$ and $\approx 462 \mathrm{MPa}$, respectively. whereas uniform and total elongations (Fig. 1B) were $\approx 24$ and $\approx 33 \%$, respectively. Yield strength of the unirradiated material measured at $420-600^{\circ} \mathrm{C}$ was $\approx 260 \mathrm{MPa}$. In Fig. 2, the yield strengths of the alloy are presented with room- and high-temperature yield strengths of other V-Ti binary and VCr-Ti ternary alloys. 15 The hydrogen content of the alloys shown in Fig. 2 was <30 appm.

Effects of displacement damage (measured on specimens irradiated in the non-DHCE) and combined effects of simultaneous displacement damage and helium generation (measured on specimens irradiated in the DHCE) are summarized in Figs. 3A-3D. In the figures, yield and ultimate tensile strengths and uniform and total elongations, measured on specimens irradiated at $425^{\circ} \mathrm{C}-600^{\circ} \mathrm{C}$ to $18-34$ dpa in the two types of experiments, have been plotted as function of irradiation temperature.

After irradiation to $\approx 30 \mathrm{dpa}$ in either a $\mathrm{DHCE}$ or a non-DHCE, ductility of the alloy remained significantly high, i.e., $>8 \%$ uniform elongation and $>10 \%$ total elongation. Lowtemperature $\left(5400^{\circ} \mathrm{C}\right)$ ductilities of the DHCE specimens were higher than those of the 

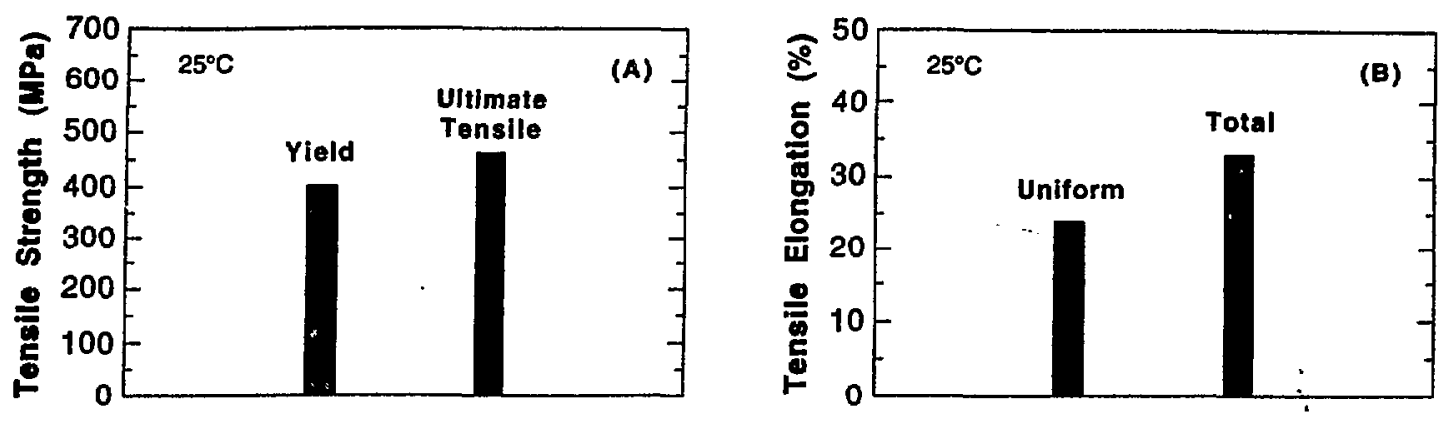

Fig. 1 Tensile strength (A) and elongation (B) of unirradiated $\mathrm{V}-4 \mathrm{Cr}-4 \mathrm{Ti}$ at $25^{\circ} \mathrm{C}$

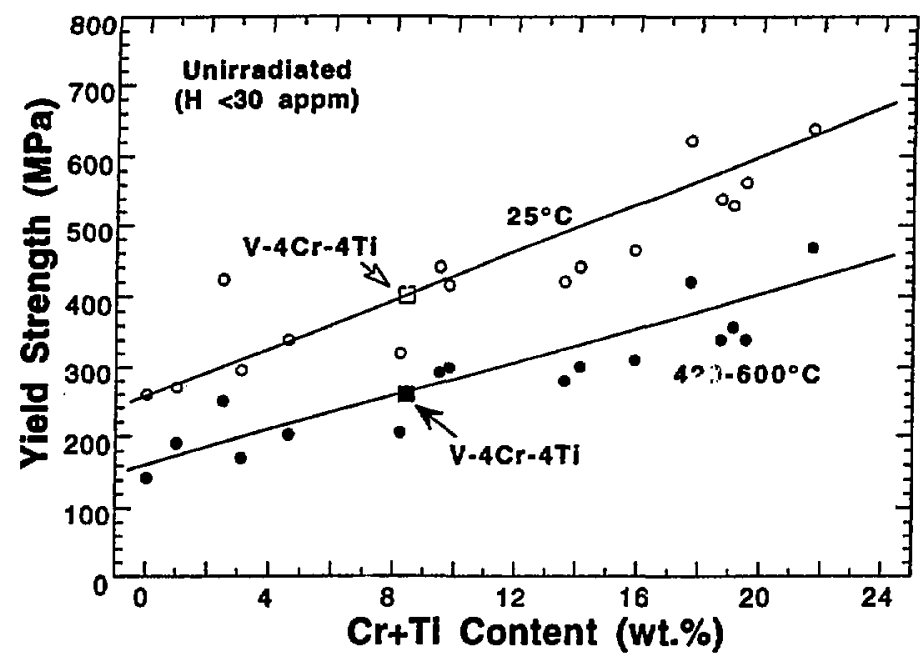

Fig. 2.

Yield strength of $V-T i$

and $V-C r-T i$ alloys as $a$

function of $\mathrm{Cr}+\mathrm{T}$ content

non-DHCE specimens, whereas strengths were lower. Although the mechanisms leading to the higher ductility and lower strength of the DHCE specimens are not understood at this time, the consistent observations indicate that different types of hardening centers are produced during the DHCE and non-DHCE irradiation.

\section{Fracture Behavior}

Fracture behavior of the alloy was investigated by Charpy-impact tests on one-thirdsize (3.3-mm-thick) V-notched $\left(45^{\circ}\right)$ specimens and by bend tests on irradiated miniature specimens. In the latter test, a TEM disk or a broken tensile specimen submerged in a low-temperature bath was bent repeatedly untll fracture, and cleavage morphology was characterized quantitatively to determine ductlle-brittle transition behavior. 

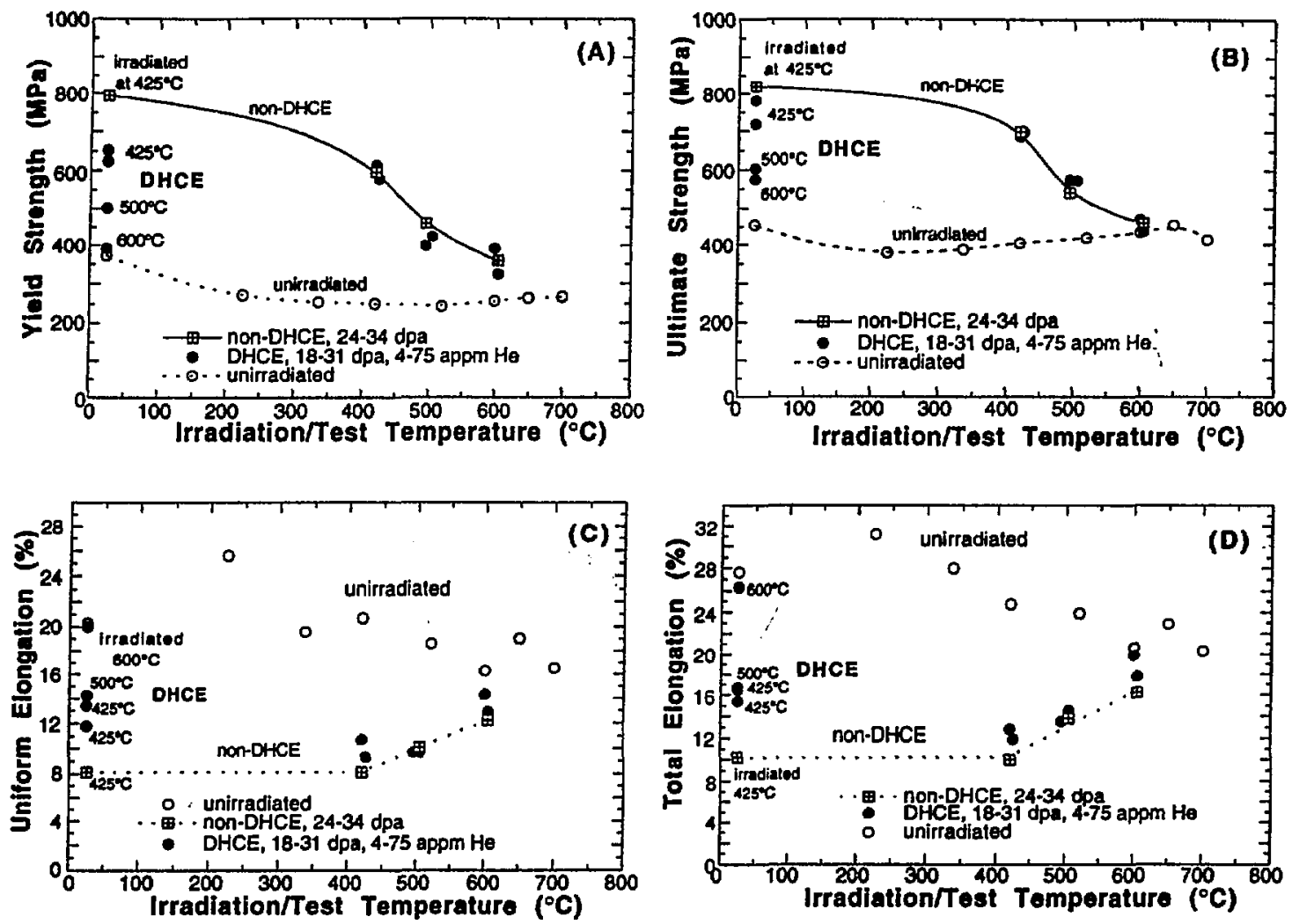

Fig. 3. Yield strength (A), ultimate tensile strength (B), uniform elongation (C), and total elongation (D) of $\mathrm{V}-4 \mathrm{Cr}-4 \mathrm{Ti}$ after irradiation at $420-600^{\circ} \mathrm{C}$ to $18-34$ dpa in the DHCE and in non-DHCE conventional irradiation (negligtble heltum generation).

Charpy-impact energy and percentage of ductile fracture surface morphology determined on unirradiated specimens from the two types of tests are plotted as a function of test temperature in Fig. 4. As shown in the figure, the alloy remained ductlle for all temperatures $>-196^{\circ} \mathrm{C}$, indicating that ductile-brittle transition temperature (DBTT) is <$200^{\circ} \mathrm{C}$. Upper-shelf Charpy energy of the alloy is $\approx 140 \mathrm{~J} / \mathrm{cm}^{2}$.

Effects of neutron displacement damage, determined on specimens irradiated at 420$600^{\circ} \mathrm{C}$ to 24-34 dpa in the non-DHCE (helfum generation negligible), are shown in Fig. 5.16 The alloy remained ductile at $>-196^{\circ} \mathrm{C}$, even after the high-dose irradiation, exhibiting a virtual immunity to dpa damage. This is a truly remarkable property considering the bcc 
structure of the alloy. The energy minimum observed at $\approx-120^{\circ} \mathrm{C}$ (surface temperature measured with spot-welded thermocouples) is believed to be associated with hydrogen concentrated in the interior of the Charpy specimen at a colder temperature.

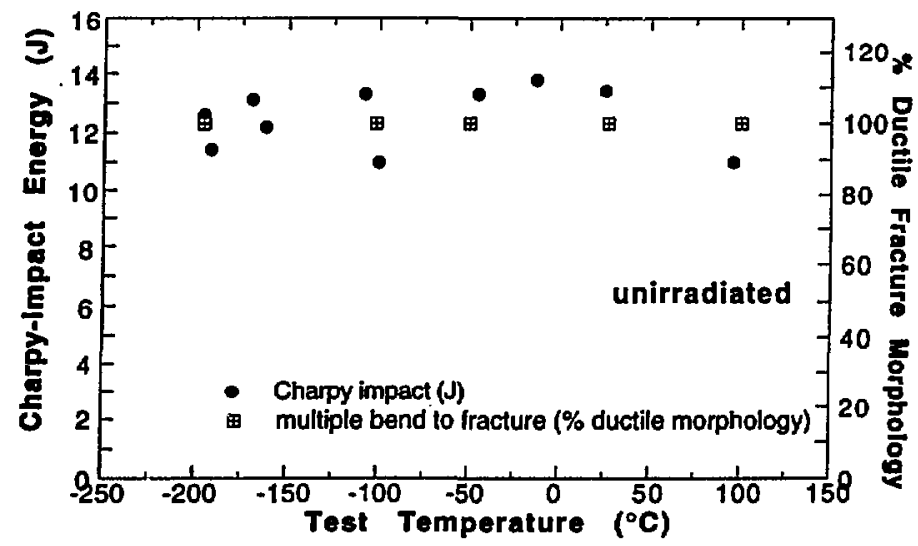

Fig. 4.

Charpy-impact energy (one-third-size) and percentage of ductile fracture surface morphology of TEM disks (determined after multiple bend until fracture) of unistadiated $V-4 C r-4 T$, plotted as a function of test temperature.

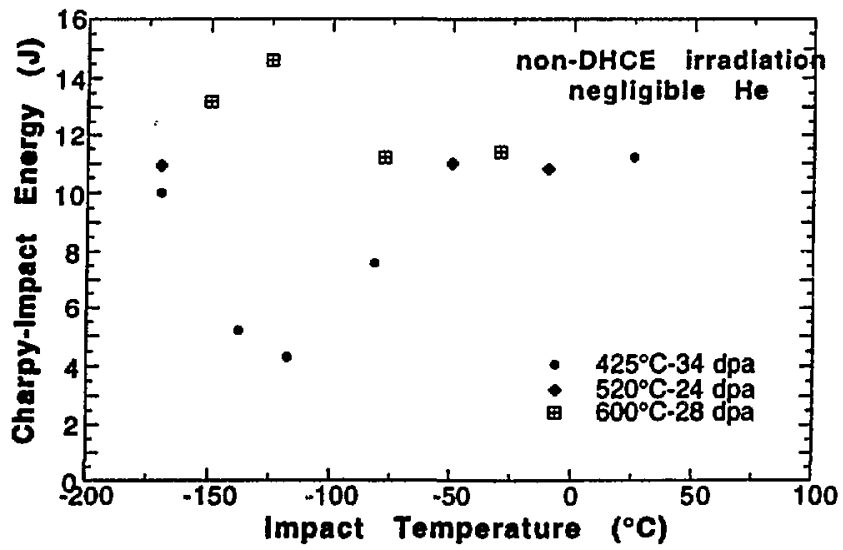

Fig. 5.

Charpy energy vs. impact temperature measured on one-third-stze specimens irradiated in the nonDHCE (negligible helium generation) to 24-34 dpa at $420-600^{\circ} \mathrm{C}$.

Effects of simultaneous displacement damage (18-31 dpa), hellum (4-75 appm, Table 2) generation, and tritlum (2-63 appm) uptake, determined on specimens irradiated at 420-600 ${ }^{\circ} \mathrm{C}$ in the DHCE, are shown in Fig. 6.17 No Charpy-impact specimens were Irradiated during the experiment. Therefore, the ductlle-brittle transition behavtor was determined from results of quantitative fractography of TEM disks (0.3-mm-thick) and broken pleces of tensile specimens (1-mm-thlck) that were fractured by repeated bending in a bath of liquid nitrogen or a mixture of acetone and dry lce. 

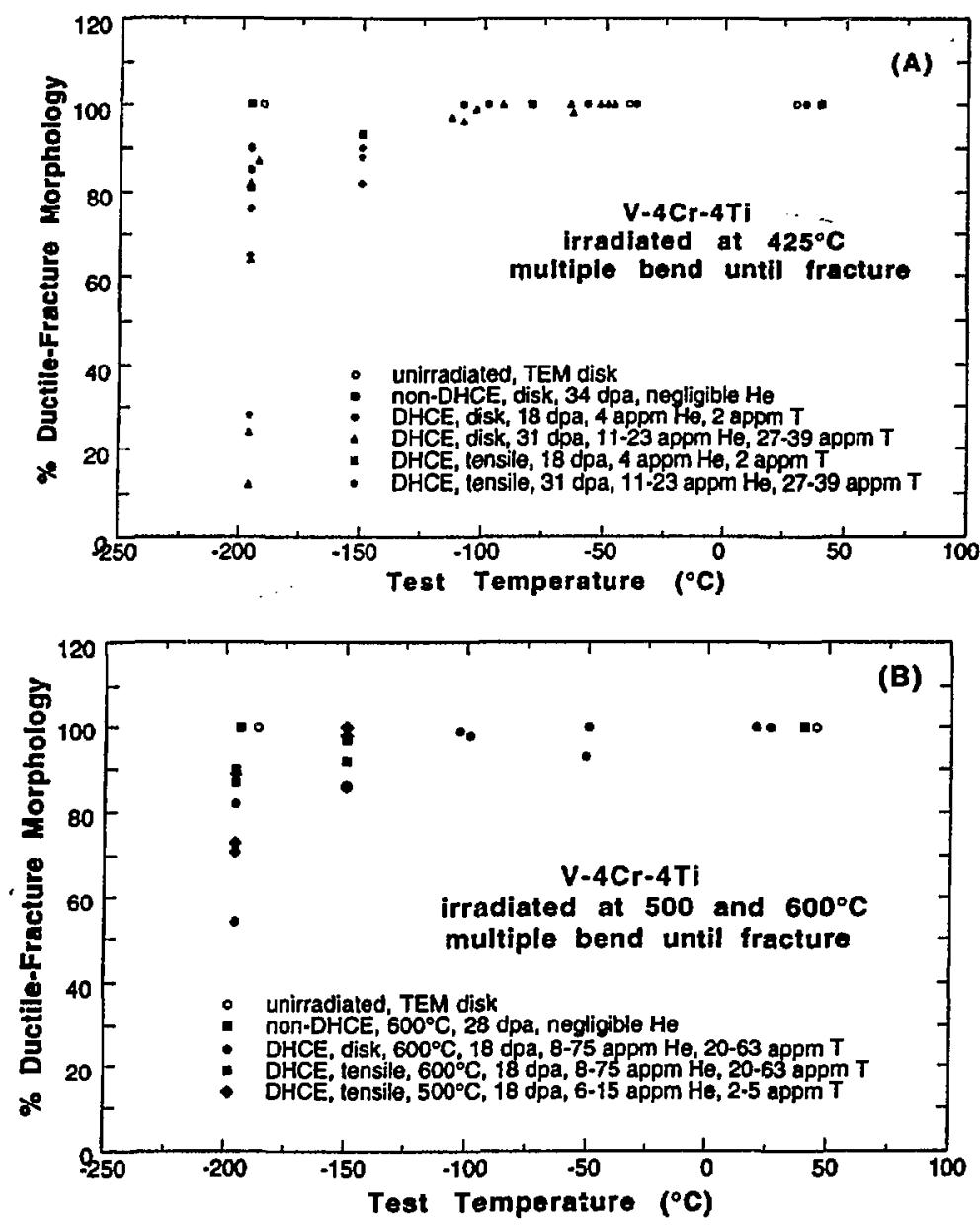

Fig. 6. Percent ductile-fracture morphologij us. test temperature of $V-4 \mathrm{Cr}-4 \mathrm{Ti}$ TEM disks and broken tensile specimens irradiated at (A) $425^{\circ} \mathrm{C}$ and $(B) 600^{\circ} \mathrm{C}$ and fractured by multiple bending.

As In Irradiation during the non-DHCE, no brittle behavior was observed at temperatures $>-150^{\circ} \mathrm{C}$ for $\mathrm{DHCE}$ specimens in which helium generation rate was $\approx 0.3-4.2$ appm helium/dpa (Table 2). Brittle-fracture surface morphology was not observed at $>120^{\circ} \mathrm{C}$, regardless of the level of dpa damage or hellum and trittum content in the alloy. Predominantly brittle-cleavage fracture morphologies were observed only at $-196^{\circ} \mathrm{C}$ in some specimens that were irradiated to $31 \mathrm{dpa}$ at $425^{\circ} \mathrm{C}$ during DHCE. No intergranular fracture was observed in any tenslle (Fig. 3) or bending-test (Fig. 6) specimens. 
One of the important findings from the DHCE was the actual measured contents of helium and tritium in the $\mathrm{V}-4 \mathrm{Cr}-4 \mathrm{Ti}$ specimens were significantly lower than those calculated based on the assumed equilibrium ratio $\left(k_{w}=0.01\right)$ of tritium in the alloy to that in the liquid lithlum (Table 2). This indicates that tritium level in lithium-cooled V-4Cr4Ti first wall/blanket structure, and hence, the effect of tritium on the fracture toughness, will be significantly less than previously assumed. However, a more comprehensive database for the effects of higher helium-dpa ratio is needed from a further investigation.

\section{Creep Properties}

Stress-rupture life and steady-state creep rate of V-4Cr-4TI and V-10Cr-5TI have been determined in a carefully controlled vacuum environment at $600^{\circ} \mathrm{C} .18$ In Fig. 7 , stressrupture behavior of $\mathrm{V}-4 \mathrm{Cr}-4 \mathrm{Tl}$ is shown in Larsen-Miller plots. For comparison, similar properties of ferritic/martensitic and austenitic steels are also included in the figure. From the figure, it is obvious that the creep strength of V-4Cr-4Ti is substantially superior to that of HT-9, Type 316 stainless steel, and V-20Ti. In particular, this difference in creep strength is more pronounced when Larsen-Miller parameters are higher, 1.e., at higher temperatures or longer times.

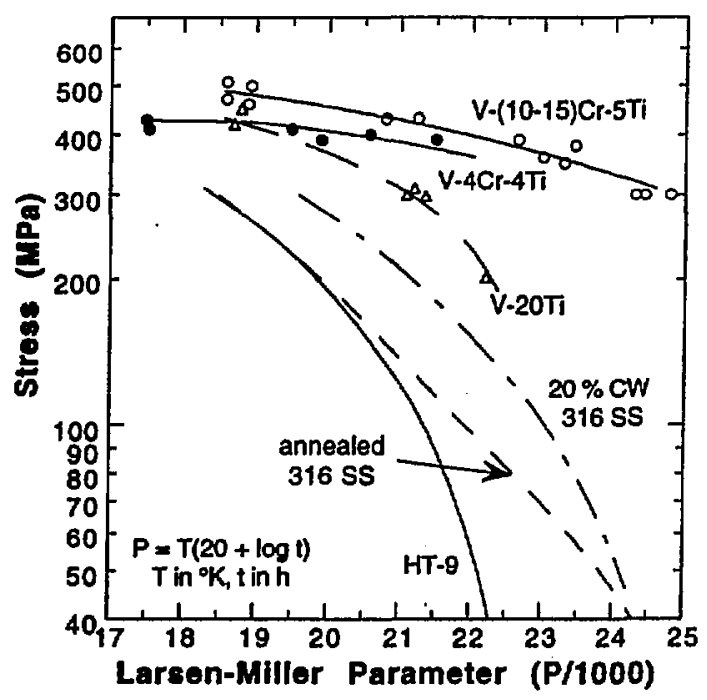

Fig. 7.

Larsen-Miller plots of creep strength of unirradiated $\mathrm{V}-4 \mathrm{Cr}-$ $4 T$ and ferritic and austenitic steels.

\section{Density Change under Irradiation}

Irradiation-induced density change and swelling behavior of $\mathrm{V}-4 \mathrm{Cr}-4 \mathrm{TI}$ have been 
Investigated after Irradiation in conventional non-DHCEs. $19 \mathrm{~V}-\mathrm{Cr}-\mathrm{Tl}$ ternary alloys exhibited swelling (density change) maxima in the damage range of 30-70 dpa, as shown in Fig. 8, and swelling decreased on irradiation to higher dpa. The swelling resistance of the alloys was associated with high-density prectpitation of ultrafine $\mathrm{Ti}_{5} \mathrm{Si}_{3}$, and it was concluded that $>4$ wt.\% $\mathrm{Ti}$ and 400-1000 wppm SI are desirable to effectively suppress swelling. ${ }^{20}$ Swelling resistance of $\mathrm{V}-4 \mathrm{Cr}-4 \mathrm{TI}$ was excellent (Fig. 8), and has been associated with ultrafine $\mathrm{T}_{5} \mathrm{~S} / 3$ for irradiation at $520-600^{\circ} \mathrm{C}$ and with dense formation of dislocation loops for irradiation at $<420^{\circ} \mathrm{C}$. 20
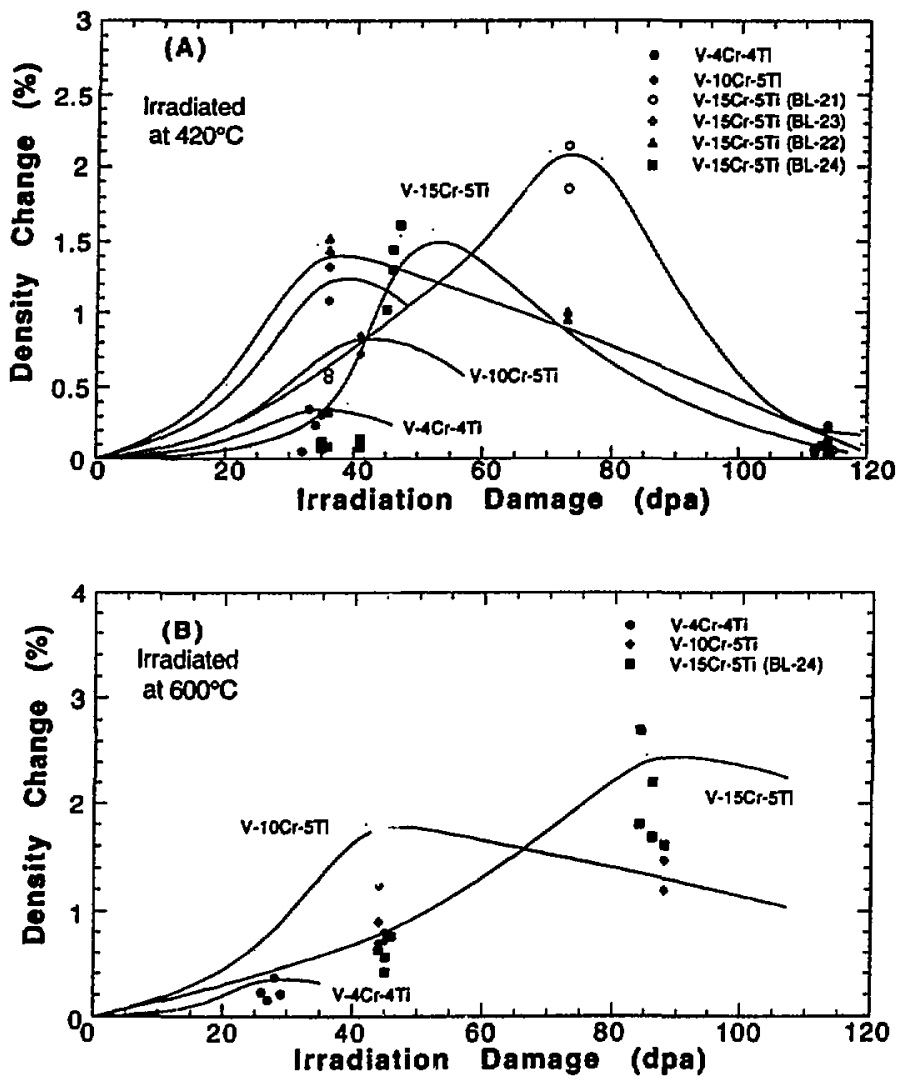

Fig. 8. Density change of $V-C r-T i$ alloys as function of dose after irradiation at (A) 420 and (B) $600^{\circ} \mathrm{C}$. Note the excellent resistance to swelling of $V-4 \mathrm{Cr}-4 \mathrm{TL}$.

Combined effects of dynamically charged hellum and neutron damage on density change, vold distribution, and microstructural evolution of $\mathrm{V}-4 \mathrm{Cr}-4 \mathrm{TI}$ have been determined after Irradiation to $18-31$ dpa at $425-600^{\circ} \mathrm{C}$ in a DHCE. 20 Results of density 
measurements for DHCE specimens are given in Fig. 9, along with the similar results from non-DHCE specimens.
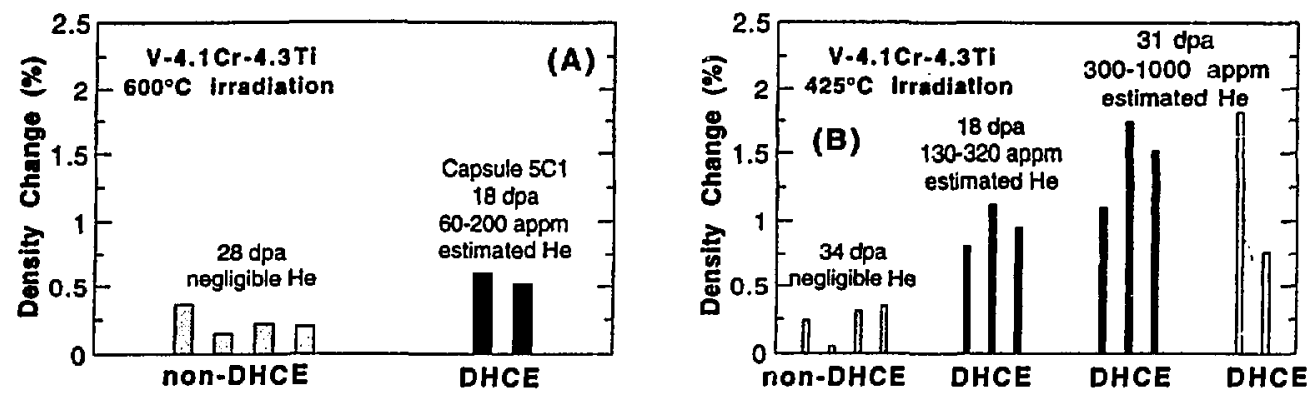

Fig. 9. Comparison of density changes of $\mathrm{V}-4 \mathrm{Cr}-4 \mathrm{Tl}$ during $\mathrm{DHCE}$ and non-DHCEs: (A) $600^{\circ} \mathrm{C}$ and (B) $425^{\circ} \mathrm{C}$.

\section{Microstructural Stability}

The primary feature of microstructural evolution during non-DHCE (negligible helium generation) irradiation at 520 and $600^{\circ} \mathrm{C}$ was high-density formation of ultrafine $\mathrm{Ti}_{5} \mathrm{Si}_{3}$ precipitates, dislocation loops, and short dislocations. 11 For irradiation at $420^{\circ} \mathrm{C}$, precipitation of Ti5Si3 was negligible, and "black-dot" defects and dislocations were observed in significantly higher densities. Despite their extremely high densities, neither black-dot defects nor $\mathrm{Ti}_{5} \mathrm{Si}_{3}$ precipitates are overly detrimental to ductility and toughness of the alloy, yet they effectively suppress irradiation-induced swelling. 9

Thermally formed Ti(O.N.C) precipitates and irradiation-induced $\mathrm{Ti}_{5} \mathrm{Si}_{3}$ precipitates, normally observed in vanadium-base alloys containing titanium, are stable during irradiation at $420-600^{\circ} \mathrm{C}$. Unstable microstructural modifications that are likely to degrade mechanical properties significantly werè not observed, e.g., irradiation-induced formation of fine oxides, carbides, nitrides, or chromium-rich clusters. As in the non-DHCE, $\mathrm{Tl}_{5} \mathrm{Si}_{3}$ did not precipitate during irradiation at $420^{\circ} \mathrm{C}$ but precipitated in similar density at $500-$ $600^{\circ} \mathrm{C}$ in the DHCE. 20

No microvoids were observed in any of the specimens irradiated at $420-600^{\circ} \mathrm{C}$ to $28-$ 34 dpa in the non-DHCE. Microvoids were observed only in DHCE specimens irradiated to -31 dpa at $425^{\circ} \mathrm{C}$ in high-tritium capsules (4D1 and 4D2, Table 2). In these specimens, moderate number densities of diffuse helium bubbles were observed in localized grain 
matrix and near limited fraction $(=15-20 \%)$ of grain boundarles. The number density of helium bubbles, observed near the limited region of grain boundaries, was significantly lower than those in other alloys tested in the tritium-trick experinients, where extensive coalescence of helium bubbles occurred on all grain boundaries.21-27 Microvolds were elther absent or negligible in $\mathrm{V}-4 \mathrm{Cr}-4 \mathrm{Tl}$ specimens irradiated in the DHCE capsules other than 4D1 and 4D2, including Capsule 5C2 (4.2 appm helium/dpa). It seems that most of

the dynamically produced helium atoms were trapped in the grain matrix without significant bubble nucleation or growth in these specimens.

\section{Conclusions}

$\mathrm{V}-4 \mathrm{wt} . \% \mathrm{Cr}-4 \mathrm{wt} . \% \mathrm{TI}$ has been identified as the most promising vanadium-base alloy for application in fusion reactor first-wall and blanket structures. A comprehensive tests have been conducted on this alloy because it exhibited the most attractive combination of the mechanical and physical properties that are prerequisites for first-wall and blanket structures, i.e., high tensile strength, high ductility, good creep properties, high impact energy, low ductile-brittle transition temperature before and after irradiation. microstructural stability, excellent resistance to irradiation-induced swelling, and good resistance to corrosion in lithium.

In particular, the alloy was found to be virtually immune to neutron displacement damage at $420-600^{\circ} \mathrm{C}$, a remarkable property compared to other candidate materials being Investigated by the fusion-reactor-materials community. Effects of helium, charged dynamically in simulation of fusion reactor conditions, on tensile, ductile-brittle transition, and swelling properties were insignificant. Ductile-brittle transition temperatures of the alloy were below $-150^{\circ} \mathrm{C}$ after irradiation to $18-31$ dpa at $425^{\circ} \mathrm{C}-600^{\circ} \mathrm{C}$ either in the dynamic helium charging experiment or in conventional irradiation (negligible helium generation). Results of analysis of tritium and hellum in specimens irradiated in the dynamic helium charging experiment indicate that tritium level in lithium-cooled $\mathrm{V}-4 \mathrm{Cr}-$ 4TI first wall/blanket structure, and hence, the effect of tritlum on the fracture toughness of the structure, will be significantly less than previously assumed. Thermal creep behavior of the alloy was also significantly superior to that of austenitic and ferritic/martensitic steels. 


\section{References}

[1] T. Noda, F. Abe, H. Araki, and M. Okada, J. Nucl. Mater. 155-157 (1988) 581.

[2] R. Santos, J. Nucl. Mater. 155-157 (1988) 589.

[3] S. J. Plet, et al., J. Nucl. Mater. 141-143 (1986) 24.

[4] F. L. Yaggee, E. R. Gilbert, and J. W. Styles, J. Less-Comm. M气t. 19 (1969) 39.

[5] D. L. Smith, B. A. Loomis, and D. R. Diercks, J. Nucl. Mater. 135 (1985) 125.

[6] B. A. Loomis, A. B. Hull, and D. L. Smith. J. Nucl. Mater., 179-181 (1991) 148-154.

[7] B. A. Loomis and D. L. Smith, J. Nucl. Mater., 191-194 (1992) 84-91.

[8] H. M. Chung and D. L. Smith, J. Nucl. Mater. 191-194 (1992) 942-947.

[9] H. M. Chung, B. A. Loomis, and D. L. Smith, ASTM STP 1175, American Society for Testing and Materials, Philadelphia, 1993, pp. 1185-1200.

[10] D. L. Smith, 3. A. Loomis, and H. M. Chung, Plasma Devices and Operations, Vol. 3, 1994. pp. i67-179.

[11] M. Sat'su and H. M. Chung, in Fusion Reactor Materials, Semiannual. Prog. Report. DOE /ER-0313/13, Oak Ridge National Laboratory, Oak Ridge, TN (1993) 227-234.

[12] H. Matsul, M. Tanno, J. Gazda, and H. M. Chung, in Fusion Reactor Materials. Semiannual. Prog. Report. DOE/ER-0313/15, Oak Ridge National Laboratory, Oak Ridge, TN (1994) 240-246.

[13] D. L. Smith, H. Matsui, L. R. Greenwood, and B. A. Loomis, J. Nucl. Mater. 155-157 (1988) 1359.

[14] D. L. Smith, B. A. Loomis, H. Matsui, M. L. Hamilton, K. L. Pearce, J. P. Kopasz, C. E. Johnson, R. G. Clemmer, and L. R. Greenwood, in Fusion Reactor Materlals. Semiannual. Prog. Report, DOE/ER-0313/10, Oak RIdge National Laboratory, Oak Ridge, TN (1991) 159.

[15] B. A. Loomis, L. J. Nowick, and D. L. Smith, in Fusion Reactor Materials. Semiannual. Prog. Report, DOE/ER-0313/15, Oak Ridge National Laboratory, Oak Ridge, TN (1994) 219-222.

[16] B. A. Loomis, H. M. Chung, L. Nowick, and D. L. Smith, in Fusion Reactor Materials. Semiannual. Prog. Report, DOE/ER-0313/15, Oak Ridge National Laboratory, Oak Rldge, TN (1994) 253-257.

[17] H. M. Chung, B. A. Loomis, H. Tsal, L. Nowicki, D. E. Busch, and D. L. Smith, "Effects of Dynamically Charged Helium on Mechanical Properties of V-4Cr-4T1," in Fusion Reactor Materials. Semiannual. Pros. Report, DOE/ER-0313/16, Oak Ridge National Laboratory, Oak Ridge, TN (1994), in press.

[18] H. M. Chung, B. A. Loomis, and D. L. Smith, in Fusion Reactor Materials, Semiannual. Proq. Report, DOE/ER-0313/14, Oak Ridge National Laboratory, Oak Ridge. TN (1993) 309-317.

[19] H. M. Chung, B. A. Loomis, L. Nowicki, J. Gazda, and D. L. Smith, in Fusion Reactor Materials, Semiannual. Prog. Report, DOE/ER-0313/15, Oak Ridge National Laboratory, Oak Ridge, TN (1994) 223-231.

[20] H. M. Chung, B. A. Loomis, H. Tsai, L. Nowicki, J. Gazda, and D. L. Smith, "Swelling and Structure of Vanadium Alloys Irradiated in the Dynamic Helium Charging Experiment," in Fusion Reactor Materials. Semiannual. Pros. Report, DOE/ER$0313 / 16$, Oak Ridge National Laboratory, Oak Ridge, TN (1994), in press.

[21] D. N. Braski and D. W. Ramey, in Effects of Radiation on Material Properties, ASTMSTP 870, F. A. Garner and J. S. Perrin, Eds., American Society for Testing and Materials, Philadelphia, 1985, pp. $1211-1224$.

[22] D. N. Braski, in Influence of Radiation on Material Properties, ASTM-STP 956, F. A. Garner, C. H. Henager, and N. Igata, Eds., American Society for Testing and Materlals, Philadelphia, 1987, pp. 271-290. 
[23] D. N. Braskd, J. Nucl. Mater. 141-143 (1986) 1125.

[24] D. N. Braskd, In Reduced Activation Materials for Fusion Reactors, ASTM-STP 1047 (1988), pp. 161-178.

[25] H. Matsuf, et al., J. Nucl. Mater. 191-194 (1992) 919.

[26] M. Satou, K. Abe, and H. Matsui, J. Nucl. Mater. 191-194 (1992) 938.

[27] M. Tanaka and H. Matsul, Mater. Trans., Japan Inst. Metals, 34 (1993) 1083. 